\title{
Pengaruh Pengendalian Internal, Moralitas Individu Dan Budaya Etis Organisasi Pada Kecenderungan Kecurangan Akuntansi
}

\author{
I Dewa Gede Praditya Chandrayatna ${ }^{1}$ \\ Maria Mediatrix Ratna Sari ${ }^{2}$ \\ ${ }^{1,2}$ Fakultas Ekonomi dan Bisnis Universitas Udayana (Unud), Bali, Indonesia \\ e-mail: pradityachandrayatna@gmail.com
}

\begin{abstract}
ABSTRAK
Penelitian ini bertujuan untuk mengetahui pengaruh pengendalian internal, moralitas individu dan budaya etis organisasi pada kecenderungan kecurangan akuntansi. Penelitian ini berlokasi di PT. Bank Pembangunan Daerah (BPD) Bali. Populasi dalam penelitian ini sebanyak 236 pegawai PT. BPD Bali. Jumlah sampel yang digunakan sebanyak 172 pegawai dengan menggunakan metode nonprobability sampling khususnya purposive sampling. Data dikumpulkan melalui metode survei dengan instrumen kuesioner. Hasil dari kuesioner penelitian ini diukur dengan menggunakan skala likert modifikasi. Teknik analisis data yang digunakan adalah teknik analisis regresi linier berganda. Berdasarkan hasil analisis regresi linier berganda ditunjukkan bahwa pengendalian internal, moralitas individu dan budaya etis organisasi berpengaruh negatif pada kecenderungan kecurangan akuntansi. Implikasi penelitian ini secara teoritis adalah mendukung teori fraud triangle dan teori perkembangan moral.
\end{abstract}

Kata kunci: Pengendalian internal, moralitas individu, budaya etis organisasi, kecenderungan kecurangan akuntansi

\begin{abstract}
This study aims to determine the effect of internal control, individual morality and organizational ethical culture on accounting fraud tendencies. This research is located at PT. Regional Development Bank (BPD) Bali. The population in this study were 236 employees of PT. BPD Bali. The number of samples used was 172 employees using the nonprobability sampling method specifically purposive sampling. Data was collected through survey methods with questionnaire instruments. The results of this research questionnaire were measured using a modified Likert scale. The data analysis technique used is multiple linear regression analysis techniques. Based on the results of multiple linear regression analysis, it is shown that internal control, individual morality and organizational ethical culture negatively influence accounting fraud tendencies. The implication of this research theoretically is supporting the theory of fraud triangle and the theory of moral development.

Keywords: internal control, individual morality, organizational ethical culture, accounting fraud tendency
\end{abstract}

\section{PENDAHULUAN}

Kecenderungan kecurangan akuntansi telah banyak menarik perhatian masyarakat sebagai dinamika yang sering terjadi di dalam dunia bisnis. Kecurangan akuntansi yang terjadi dalam organisasi dipandang sebagai suatu ancaman serius oleh para pemangku kepentingan, yang ditandai dengan meningkatnya kejahatan ekonomi 
I Dewa Gede Praditya Chandrayatna dan Maria Madiatrix Ratna Sari. Pengaruh ...

(Mangala dan Kumari, 2017). Untuk meminimalisir ancaman tersebut, setiap perusahaan wajib memenuhi tuntutan stakeholder dengan mewujudkan good corporate governance. Salah satu prinsip dasar dalam penyelenggaraan good corporate governance yaitu akuntabilitas dengan media laporan keuangan. Mengingat pentingnya informasi yang terkandung dalam laporan keuangan, maka harus disusun sesuai dengan standar akuntansi yang berlaku.

Dalam menghasilkan laporan keuangan yang relevan dan dapat diandalkan, tidak menutup kemungkinan akan terjadinya kesalahan penyajian dalam laporan keuangan. Terdapat dua jenis kesalahan penyajian yaitu kecurangan dan kekeliruan. Istilah kecurangan berbeda dengan istilah kekeliruan (Simanjuntak dkk., 2015). Jika tindakan tersebut dilakukan secara sengaja, maka disebut kecurangan dan jika tindakan tersebut dilakukan secara tidak sengaja, maka disebut kekeliruan

Kecurangan dalam lingkup akuntansi merupakan penyimpangan dari standar akuntansi yang seharusnya diterapkan oleh suatu organisasi (Wulandari dan Zaky, 2014). Kecenderungan kecurangan akuntansi (fraud) dapat didefinisikan sebagai suatu tindakan yang mengakibatkan kesalahan pelaporan dalam laporan keuangan atau tindakan kesengajaan dalam menggunakan sumber daya organisasi secara tidak wajar dan salah menyajikan fakta untuk memperoleh keuntungan pribadi (Apriadi dan Fachriyah, 2014). Kecenderungan kecurangan akuntansi dapat menimbulkan kerugian yang besar bagi suatu perusahaan dan mampu menciptakan masalah moral di tempat kerja (Salem, 2012). Kerugian tersebut merupakan masalah serius yang perlu dikendalikan. 
Kecenderungan kecurangan akuntansi dapat berupa penghilangan jumlah atau pengungkapan dalam laporan keuangan untuk mengelabui pemakai laporan keuangan. Dalam lingkup entitas bisnis, kecurangan akuntansi dapat berupa perubahan laba perusahaan agar terlihat menguntungkan (Bhasin, 2013). Adapun dampak yang dapat ditimbulkan dari kecurangan akuntansi yaitu menurunnya efisiensi dan kepercayaan publik terhadap laporan keuangan perusahaan (Ozcan, 2016). Sebagian besar kecurangan akuntansi dilakukan oleh karyawan atau orang luar yang berkolusi dengan karyawan (Kuria dan Muturi, 2015).

Association of Certified Fraud Examiners (2014) menjelaskan bahwa kecurangan akuntansi dapat diklasifikasikan menjadi tiga jenis, yaitu kecurangan dalam laporan keuangan, penyalahgunaan aset dan korupsi. Kecurangan akuntansi dapat ditunjukkan melalui tingkat korupsi suatu negara (Gaviria, 2002). Liu (2016) menjelaskan bahwa korupsi merupakan tindakan yang dilakukan oleh seorang pejabat secara tidak sah untuk memperoleh keuntungan pribadi.

Indonesia tergolong sebagai salah satu negara dengan tingkat korupsi yang masih tinggi. Hal ini dibuktikan dengan adanya kasus korupsi di Indonesia yang mengalami peningkatan. Indonesia Corruption Watch (ICW) menyatakan bahwa terdapat 576 kasus korupsi sepanjang tahun 2017, angka ini bertambah dibandingkan tahun 2016 dengan 482 kasus (tempo.co).

Transparency International (TI) setiap tahunnya meluncurkan Corruption Perception Index (CPI). Corruption perception index merupakan sebuah indeks pengukuran tingkat korupsi global. Pada tahun 2017, skor CPI Indonesia adalah 37 dan berada pada peringkat 96 dari 180 negara yang disurvei (kpk.go.id). Skor 
CPI Indonesia pada tahun 2017 berada pada poin yang sama dengan tahun 2016. Hal ini menunjukkan bahwa telah terjadinya stagnasi dalam pencegahan dan pemberantasan korupsi di Indonesia oleh berbagai pihak. Dengan demikian, Indonesia masih belum mampu keluar dari situasi korupsi.

Kasus mengenai kecenderungan kecurangan akuntansi sering terjadi pada lembaga keuangan. Otoritas Jasa Keuangan (OJK) mencatat sebanyak 108 kasus kecurangan akuntansi terjadi pada lembaga keuangan sepanjang tahun 2016 (liputan6.com). Salah satu lembaga keuangan tersebut adalah PT. Bank Pembangunan Daerah (BPD) Bali. PT. BPD Bali tergolong sebagai salah satu bank yang berperan penting dalam meningkatkan perekonomian daerah Bali.

Berdasarkan berita yang diperoleh, telah terjadi kasus kecenderungan kecurangan akuntansi di PT. BPD Bali Cabang Renon pada tahun 2014 yang merugikan keuangan negara hingga Rp337.000.000. Kasus tersebut dilatarbelakangi dengan adanya tindak korupsi pegawai bagian dana dan jasa yang melakukan pembatalan penyetoran uang dari wajib pajak tanpa persetujuan Kepala UPT Samsat Online, selanjutnya uang pembatalan tersebut digunakan untuk kepentingan pribadi (bali.tribunnews.com). Selain itu, pada tahun 2016 juga telah terjadi kasus fraud di PT. BPD Bali cabang Tabanan. Kasus tersebut dilatarbelakangi dengan adanya tindak korupsi pegawai bank yang merugikan dana nasabah hingga 1,7 miliar rupiah. Dalam menjalankan aksinya, pelaku mendepositokan uang nasabah sebesar satu miliar rupiah dan dimasukkan ke sistem komputer. Selanjutnya, pengambilan bunga deposito dilakukan oleh pelaku dan buktinya dihapuskan serta diserahkan lagi ke nasabah (bali.tribunnews.com). 
Tuanakotta (2010: 207) menjelaskan faktor-faktor penyebab terjadinya kecurangan tidak terlepas dari konsep fraud triangle yaitu tekanan (pressure), kesempatan (opportunity), dan rasionalisasi (rationalization). Tekanan yang dimaksud adalah adanya kebutuhan keuangan yang mendesak, di mana karyawan akan berperilaku curang untuk memenuhi kebutuhan ekonomi. Peluang berarti terdapat suatu situasi yang mengakibatkan individu melakukan fraud secara diamdiam. Rasionalisasi menunjukkan sikap lembaga untuk merasionalkan atau mencari pembenaran sebelum melakukan tindakan curang.

Kecenderungan kecurangan akuntansi dapat dipengaruhi oleh lemahnya pengendalian internal, faktor dari dalam diri individu (internal) dan faktor organisasi (eksternal). Pengendalian internal merupakan serangkaian proses yang dilakukan untuk melindungi aset perusahaan dari penyalahgunaan, memastikan informasi usaha yang disajikan telah akurat dan meyakinkan bahwa hukum serta peraturan telah diikuti (Muhammad dan Ridwan, 2017). Teori fraud triangle mengungkapkan bahwa terdapat tiga faktor yang mendorong seseorang melakukan tindakan kecenderungan kecurangan akuntansi, salah satunya adalah kesempatan (opportunity). Faktor kesempatan dapat mengakibatkan pelaku dengan leluasa melakukan tindakan kecurangan. Semakin besar kesempatan, maka kecenderungan kecurangan akuntansi akan lebih sering terjadi. Kecenderungan kecurangan akuntansi dapat diminimalisir dengan adanya pengendalian internal yang efektif. Pengendalian internal berfungsi mengurangi faktor kesempatan yang mendorong dilakukannya tindakan kecurangan (Hogan et al., 2008). Pengendalian internal diterapkan untuk menentukan strategi jangka 
I Dewa Gede Praditya Chandrayatna dan Maria Madiatrix Ratna Sari. Pengaruh ...

panjang dan meningkatkan efisiensi suatu entitas (Leng dan Zhang, 2014). Coram et al. (2008) menjelaskan bahwa pengendalian internal berperan penting dalam mencegah terjadinya kecurangan akuntansi. Semakin tinggi tingkat pengendalian internal yang diterapkan dalam suatu organisasi, maka kecenderungan kecurangan akuntansi semakin rendah.

Berdasarkan penelitian yang dilakukan oleh Putri (2014), Sari dkk. (2015), Lestari dan Supadmi (2017) menyatakan bahwa pengendalian internal berpengaruh negatif dan signifikan pada kecurangan akuntansi. Hasil tersebut juga sejalan dengan penelitian yang dilakukan oleh Restiana dan Amirya (2015) menunjukkan bahwa efektivitas sistem pengendalian internal berpengaruh negatif terhadap terjadinya fraud. Berdasarkan uraian tersebut, maka hipotesis dapat dirumuskan sebagai berikut:

$\mathrm{H}_{1}$ : Pengendalian internal berpengaruh negatif pada kecenderungan kecurangan akuntansi

Kecenderungan kecurangan akuntansi juga dipengaruhi oleh faktor dari dalam individu, yaitu moralitas individu. Moralitas individu dapat didefinisikan sebagai sikap dan perilaku yang baik, di mana setiap individu akan berusaha melakukan tugasnya sebaik mungkin dan tidak meminta balasan (Udayani dan Sari, 2017). Moralitas dapat terjadi jika individu mengambil tindakan yang baik karena ia sadar akan tanggung jawabnya dan bukan karena ingin mencari keuntungan (Mukino dkk., 2016). Salah satu teori perkembangan moral yang digunakan adalah teori mengenai level penalaran moral Kohlberg. Teori Kohlberg berpandangan bahwa penalaran moral sebagai landasan dari perilaku etis. Level penalaran moral individu akan memengaruhi perilaku etis mereka (Liyanarachchi 
dan Newdick, 2009). Semakin tinggi tahapan moralitas individu atau mencapai tahap pascakonvensional, maka individu akan lebih memperhatikan kepentingan secara universal daripada organisasinya apalagi dirinya sendiri.

Berdasarkan penelitian yang dilakukan oleh Indriastuti dkk. (2016) dan Udayani dan Sari (2017) menyimpulkan bahwa moralitas individu berpengaruh negatif terhadap kecurangan akuntansi. Hasil tersebut juga sejalan dengan penelitian yang dilakukan oleh Anastasia dan Sparta (2014) serta Eliza (2015) berpendapat bahwa moralitas individu berpengaruh negatif dan signifikan terhadap tingkat kecenderungan kecurangan akuntansi. Berdasarkan uraian tersebut, maka hipotesis dapat dirumuskan sebagai berikut:

$\mathrm{H}_{2}$ : Moralitas individu berpengaruh negatif pada kecenderungan kecurangan akuntansi

Budaya etis organisasi juga merupakan variabel yang dapat memengaruhi terjadinya kecenderungan kecurangan akuntansi. Budaya organisasi dapat mendorong terciptanya perilaku etis dan perilaku tidak etis. Budaya etis organisasi dapat didefinisikan sebagai pola sikap yang dimiliki oleh masing-masing anggota organisasi dan dapat membentuk budaya organisasi yang sejalan dengan tujuan organisasi (Fachrunisa dkk., 2015). Teori fraud triangle mengungkapkan bahwa terdapat tiga faktor yang mendorong seseorang melakukan tindakan kecenderungan kecurangan akuntansi, salah satunya adalah rasionalisasi (rasionalization). Faktor rasionalisasi menjelaskan bahwa sikap, karakter, atau serangkaian nilai-nilai etis yang memperbolehkan pegawai untuk melakukan tindakan yang tidak jujur, atau mereka berada dalam lingkungan yang cukup menekan sehingga mendorong mereka merasionalisasi tindakan yang tidak jujur. 
I Dewa Gede Praditya Chandrayatna dan Maria Madiatrix Ratna Sari. Pengaruh ...

Jika tingkat budaya etis organisasi rendah, maka setiap individu dalam suatu organisasi akan cenderung melakukan kecurangan akuntansi. Sebaliknya, jika suatu organisasi telah ditanamkan nilai-nilai yang baik, seperti kecurangan akuntansi merupakan tindakan yang tidak baik dan merugikan banyak pihak, maka pegawai cenderung tidak akan melakukan kecurangan akuntansi. Jadi, semakin baik budaya etis organisasi dalam suatu organisasi maka akan semakin rendah tingkat terjadinya kecenderungan kecurangan akuntansi.

Berdasarkan hasil penelitian yang dilakukan oleh Artini dkk. (2014), Lestari dkk. (2015) dan Zainuddin (2016) menyimpulkan bahwa budaya etis organisasi berpengaruh negatif dan signifikan terhadap kecenderungan kecurangan akuntansi. Berdasarkan uraian tersebut, maka hipotesis dapat dirumuskan sebagai berikut:

$\mathrm{H}_{3}$ : Budaya etis organisasi berpengaruh negatif pada kecenderungan kecurangan akuntansi

\section{METODE PENELITIAN}

Desain penelitian dalam penelitian ini menggunakan pendekatan kuantitatif yang berbentuk asosiatif. Pendekatan asosiatif merupakan penelitian yang bertujuan untuk mengetahui pengaruh antara dua variabel atau lebih. Hubungan yang diteliti dalam penelitian berupa hubungan kausal, yaitu hubungan sebab akibat antar variabel.

Penelitian ini berlokasi di PT. Bank Pembangunan Daerah (BPD) Bali. Lokasi tersebut dipilih karena PT. BPD Bali tergolong sebagai salah satu bank umum yang berperan penting dalam meningkatkan perekonomian Bali. Selain itu, 
telah terjadi beberapa kasus kecurangan akuntansi di PT. Bank Pembangunan Daerah Bali, diantaranya: (a) Pada tahun 2014, telah terjadi kasus kecurangan akuntansi di PT. BPD Bali Cabang Renon yang merugikan keuangan negara hingga Rp337.000.000; dan (b) Kasus kecurangan akuntansi juga telah terjadi pada tahun 2016 di PT. BPD Bali cabang Tabanan yang merugikan dana nasabah hingga 1,7 miliar rupiah.

Variabel-variabel yang digunakan dalam penelitian ini adalah variabel dependen dan variabel independen. Variabel dependen dalam penelitian ini adalah kecenderungan kecurangan akuntansi. Kecenderungan kecurangan akuntansi merupakan suatu tindakan yang dilakukan untuk memperoleh keuntungan pribadi secara tidak wajar seperti menutupi kebenaran, penipuan, manipulasi, kelicikan atau mengelabui yang dapat berupa salah saji atas laporan keuangan, korupsi dan penyalahgunaan aset. Dalam mengukur variabel kecenderungan kecurangan akuntansi digunakan lima indikator yaitu: (a) Kecenderungan untuk melakukan manipulasi, pemalsuan, atau perubahan catatan akuntansi atau dokumen pendukungnya; (b) Kecenderungan untuk melakukan penyajian yang salah atau penghilangan peristiwa, transaksi, atau informasi yang signifikan dari laporan keuangan; (c) Kecenderungan untuk melakukan salah menerapkan prinsip akuntansi secara sengaja; (d) Kecenderungan untuk melakukan penyajian laporan keuangan yang salah akibat pencurian (penyalahgunaan atau penggelapan) terhadap aktiva yang membuat entitas membayar barang atau jasa yang tidak diterima; (e) Kecenderungan untuk melakukan penyajian laporan keuangan yang salah akibat perlakuan yang tidak semestinya terhadap aktiva dan disertai dengan 
catatan atau dokumen palsu dan menyangkut satu atau lebih individu di antara manajemen, karyawan atau pihak ketiga.

Variabel independen pertama dalam penelitian ini adalah pengendalian internal. Pengendalian internal merupakan serangkaian proses yang dilakukan untuk melindungi aset perusahaan dari penyalahgunaan, memastikan informasi usaha yang disajikan telah akurat dan meyakinkan bahwa hukum serta peraturan telah diikuti. Dalam mengukur variabel pengendalian internal digunakan lima indikator yaitu: (a) Lingkungan pengendalian; (b) Penilaian risiko; (c) Aktivitas pengendalian; (d) Informasi dan komunikasi; (e) Pemantauan.

Variabel independen kedua dalam penelitian ini adalah moralitas individu. Moralitas individu merupakan sikap dan perilaku yang baik, di mana setiap individu akan berusaha melakukan tugasnya sebaik mungkin dan tidak meminta balasan. Dalam mengukur variabel moralitas individu digunakan tiga indikator yang mengacu pada teori mengenai level penalaran moral Kohlberg, yaitu: (a) Prakonvensional; (b) Konvensional; (c) Pascakonvensional. Penelitian ini menggunakan skenario yang memuat kasus dilema etika.

Variabel independen ketiga dalam penelitian ini adalah budaya etis organisasi. Budaya etis organisasi merupakan pola sikap yang dimiliki oleh masing-masing anggota organisasi dan dapat membentuk budaya organisasi yang sejalan dengan tujuan organisasi. Dalam mengukur variabel budaya etis organisasi digunakan lima indikator yaitu: (a) Model peran yang visible; (b) Komunikasi harapan etis; (c) Pelatihan etis; (d) Hukuman bagi tindakan etis; (e) Mekanisme perlindungan etika. 
Populasi dalam penelitian ini adalah seluruh kepala cabang dan pegawai yang bekerja pada setiap divisi di PT. Bank Pembangunan Daerah Bali. Dalam penelitian ini, sampel yang digunakan sebanyak 172 pegawai PT. BPD Bali dari keseluruhan populasi yang berjumlah 236 pegawai. Teknik penentuan sampel yang digunakan dalam penelitian adalah teknik nonprobability sampling khususnya purposive sampling, yaitu teknik penentuan sampel dengan menggunakan pertimbangan tertentu (Sugiyono, 2017: 144). Adapun kriteria tersebut antara lain: (a) Kepala cabang dan pegawai pada setiap divisi di PT. BPD Bali yang memiliki pendidikan terakhir minimum sarjana (S1) dan (b) Kepala cabang dan pegawai pada setiap divisi di PT. BPD Bali yang sudah bekerja minimum 3 tahun.

Metode pengumpulan data yang digunakan dalam penelitian ini yaitu metode kuesioner dan wawancara. Kuesioner merupakan suatu teknik pengumpulan data yang dilakukan dengan cara memberi sejumlah pertanyaan atau pernyataan tertulis kepada responden untuk dijawab (Sugiyono, 2017: 225). Hasil jawaban responden kemudian diukur dengan menggunakan skala likert modifikasi. Wawancara dilakukan dengan kepala cabang dan pegawai yang bekerja pada masing-masing divisi PT, BPD Bali mengenai gambaran umum bank, struktur organisasi, job description dan budaya etis yang diterapkan organisasi.

Penelitian ini melakukan uji instrumen yang bertujuan untuk mengetahui seberapa besar tingkat keakuratan dan konsistensi data yang dikumpulkan. Uji instrumen dalam penelitian ini terdiri dari uji validitas dan uji reliabilitas. Data 
ordinal (skor kuesioner) dalam penelitian ini terlebih dahulu ditransformasi menjadi data interval dengan Method of Successive Interval (MSI). Selanjutnya, peneliti melakukan pengujian statistik deskriptif. Statistik deskriptif digunakan untuk menjelaskan variabel-variabel yang diteliti.

Uji asumsi klasik dilakukan sebelum analisis regresi berganda untuk memastikan bahwa model yang diajukan benar-benar memenuhi asumsi dasar dalam analisis regresi. Uji asumsi klasik yang digunakan dalam penelitian terdiri dari uji normalitas, uji multikolinearitas dan uji heteroskedastisitas. Teknik analisis yang digunakan dalam penelitian ini adalah analisis regresi berganda yang bertujuan untuk membantu memprediksi nilai suatu variabel dependen oleh lebih dari variabel independen (Suyana Utama, 2016: 77). Model regresi linear berganda yang digunakan adalah dengan menggunakan rumus:

$$
Y=\alpha+\beta_{1} X_{1}+\beta_{2} X_{2}+\beta_{3} X_{3}+e
$$

Keterangan:

$\mathrm{Y} \quad=$ Kecenderungan Kecurangan Akuntansi

$\alpha \quad=$ Konstanta

$\beta_{1} \quad=$ Koefisien regresi variabel pengendalian internal

$\beta_{2} \quad=$ Koefisien regresi variabel moralitas individu

$\beta_{3} \quad=$ Koefisien regresi variabel budaya etis organisasi

$\mathrm{X}_{1} \quad=$ Pengendalian internal

$\mathrm{X}_{2} \quad=$ Moralitas individu

$\mathrm{X}_{3} \quad=$ Budaya etis organisasi

e $\quad=$ Error

Selain itu, penelitian ini juga disertai dengan uji goodness of fit. Secara statistik hal tersebut dapat dilihat dari nilai koefisien determinasi $\left(\mathrm{R}^{2}\right)$, nilai statistik F (uji kelayakan model), dan nilai statistik t (uji statistik parameter individual). 


\section{HASIL DAN PEMBAHASAN}

Penelitian ini dilakukan untuk mengetahui pengaruh pengendalian internal, moralitas individu dan budaya etis organisasi pada kecenderungan kecurangan akuntansi di PT. Bank Pembangunan Daerah Bali. Adapun proses seleksi berdasarkan kreteria disajikan dalam Tabel 1, sebagai berikut:

Tabel 1.

Seleksi Sampel Berdasarkan Kriteria

\begin{tabular}{clc}
\hline No. & \multicolumn{1}{c}{ Kriteria } & \multicolumn{1}{c}{ Sampel } \\
\hline 1 & $\begin{array}{l}\text { Seluruh kepala cabang dan pegawai pada masing-masing } \\
\text { divisi di PT. BPD Bali }\end{array}$ & 236 orang \\
2 & $\begin{array}{l}\text { Kepala cabang dan pegawai pada masing-masing divisi } \\
\text { PT. BPD Bali yang memiliki pendidikan terakhir di } \\
\text { bawah sarjana (S1) }\end{array}$ & $(27)$ \\
Kepala cabang dan pegawai pada masing-masing divisi \\
PT. BPD Bali yang bekerja di bawah 3 tahun \\
Total sampel berdasarkan kriteria
\end{tabular}

Sumber: Data diolah, 2018

Berdasarkan Tabel 1 dapat dilihat bahwa jumlah sampel yang digunakan dalam penelitian ini sebanyak 172 orang. Pengumpulan data yang dilakukan melalui penyebaran kuesioner kepada PT. Bank Pembangunan Daerah Bali. Penyebaran kuesioner dilakukan hingga semua kuesioner terjawab dan terkumpul memerlukan waktu selama 25 hari, yaitu mulai tanggal 10 September sampai dengan 5 Oktober 2018. Berdasarkan hasil seleksi sampel, kuesioner yang disebar sebanyak 172 eksemplar. Dari 172 kuesioner, yang dikembalikan sebanyak 172 kuesioner sedangkan yang tidak dikembalikan 0 dari pihak PT. BPD Bali. Dalam penelitian ini seluruh kuesioner yang dikembalikan memiliki jawaban lengkap, sehingga tidak ada kuesioner yang gugur. Perhitungan dari data tersebut menghasilkan tingkat pengembalian responden sebesar $100 \%$ dan tingkat pengembalian yang dapat digunakan sebesar $100 \%$. Karakteristik responden yang 
I Dewa Gede Praditya Chandrayatna dan Maria Madiatrix Ratna Sari. Pengaruh ...

diteliti meliputi jenis kelamin, umur, jabatan, pendidikan terakhir, dan lama bekerja.

Uji validitas dilakukan dengan menghitung korelasi bivariate antara masing-masing skor indikator dengan total skor. Suatu instrumen dikatakan valid jika koefisien korelasi (r) hitung lebih besar dari 0,30 ( $r>0,30)$. Sedangkan, jika $r$ hitung lebih kecil dari 0,30 maka butir pertanyaan atau pernyataan dinyatakan tidak valid. Hasil uji validitas dapat dilihat pada Tabel 2 sebagai berikut:

Tabel 2.

Hasil Uji Validitas

\begin{tabular}{|c|c|c|c|c|}
\hline No. & Variabel & Kode Instrumen & $\begin{array}{c}\text { Nilai Pearson } \\
\text { Correlation }\end{array}$ & Keterangan \\
\hline \multirow[t]{27}{*}{1} & Pengendalian Internal $\left(\mathrm{X}_{1}\right)$ & $\mathrm{X} 1.1$ & 0,919 & Valid \\
\hline & & $\mathrm{X} 1.2$ & 0,890 & Valid \\
\hline & & $\mathrm{X} 1.3$ & 0,926 & Valid \\
\hline & & $\mathrm{X} 1.4$ & 0,885 & Valid \\
\hline & & $\mathrm{X} 1.5$ & 0,884 & Valid \\
\hline & & X1.6 & 0,901 & Valid \\
\hline & & $\mathrm{X} 1.7$ & 0,879 & Valid \\
\hline & & $\mathrm{X} 1.8$ & 0,924 & Valid \\
\hline & & $\mathrm{X} 1.9$ & 0,858 & Valid \\
\hline & & $\mathrm{X} 1.10$ & 0,941 & Valid \\
\hline & & $\mathrm{X} 1.11$ & 0,896 & Valid \\
\hline & & $\mathrm{X} 1.12$ & 0,918 & Valid \\
\hline & & $\mathrm{X} 1.13$ & 0,894 & Valid \\
\hline & & $\mathrm{X} 1.14$ & 0,918 & Valid \\
\hline & & $\mathrm{X} 1.15$ & 0,931 & Valid \\
\hline & & $\mathrm{X} 1.16$ & 0,915 & Valid \\
\hline & & $\mathrm{X} 1.17$ & 0,894 & Valid \\
\hline & & $\mathrm{X} 1.18$ & 0,933 & Valid \\
\hline & & $\mathrm{X} 1.19$ & 0,940 & Valid \\
\hline & & $\mathrm{X} 1.20$ & 0,929 & Valid \\
\hline & & $\mathrm{X} 1.21$ & 0,922 & Valid \\
\hline & & $\mathrm{X} 1.22$ & 0,910 & Valid \\
\hline & & $\mathrm{X} 1.23$ & 0,905 & Valid \\
\hline & & $\mathrm{X} 1.24$ & 0,902 & Valid \\
\hline & & $\mathrm{X} 1.25$ & 0,880 & Valid \\
\hline & & $\mathrm{X} 1.26$ & 0,907 & Valid \\
\hline & & $\mathrm{X} 1.27$ & 0,892 & Valid \\
\hline \multirow[t]{6}{*}{2} & Moralitas Individu & $\mathrm{X} 2.1$ & 0,943 & Valid \\
\hline & $\left(\mathrm{X}_{2}\right)$ & $\mathrm{X} 2.2$ & 0,886 & Valid \\
\hline & & $\mathrm{X} 2.3$ & 0,943 & Valid \\
\hline & & $\mathrm{X} 2.4$ & 0,889 & Valid \\
\hline & & $\mathrm{X} 2.5$ & 0,941 & Valid \\
\hline & & $\mathrm{X} 2.6$ & 0,941 & Valid \\
\hline 3 & Budaya Etis Organisasi & $\mathrm{X} 3.1$ & 0,921 & Valid \\
\hline
\end{tabular}




$\begin{array}{lccr} & \text { X3.2 } & 0,943 & \text { Valid } \\ & \text { X3.3 } & 0,928 & \text { Valid } \\ & \text { X3.4 } & 0,921 & \text { Valid } \\ & \text { X3.5 } & 0,949 & \text { Valid } \\ \text { Kecenderungan Kecurangan } & \text { Y.1 } & 0,925 & \text { Valid } \\ \text { Akuntansi (Y) } & \text { Y.2 } & 0,865 & \text { Valid } \\ & \text { Y.3 } & 0,919 & \text { Valid } \\ & \text { Y.4 } & 0,916 & \text { Valid } \\ & \text { Y.5 } & 0,872 & \text { Valid } \\ & \text { Y.6 } & 0,924 & \text { Valid } \\ & \text { Y.7 } & 0,901 & \text { Valid } \\ & \text { Y.8 } & 0,910 & \text { Valid } \\ & \text { Y.9 } & 0,898 & \text { Valid } \\ & \text { Y.10 } & 0,887 & \text { Valid } \\ & \text { Y.11 } & 0,917 & \text { Valid } \\ & \text { Y.12 } & 0,940 & \text { Valid } \\ & \text { Y.13 } & 0,966 & \text { Valid } \\ & \text { Y.14 } & 0,927 & \text { Valid }\end{array}$

Sumber: Data diolah, 2018

Berdasarkan Tabel 2 dapat disimpulkan bahwa instrumen penelitian yang terdiri dari item-item pernyataan pengendalian internal $\left(\mathrm{X}_{1}\right)$, moralitas individu $\left(\mathrm{X}_{2}\right)$, budaya etis organisasi $\left(\mathrm{X}_{3}\right)$, dan kecenderungan kecurangan akuntansi ( $\left.\mathrm{Y}\right)$ memiliki nilai pearson correlation positif dan nilainya lebih besar dari 0,30 . Jadi, seluruh indikator pernyataan tersebut telah memenuhi syarat validitas data.

Uji reliabilitas data dilakukan dengan melihat nilai cronbach's alpha. Jika nilai cronbach's alpha lebih besar dari 0,60 maka butir-butir pertanyaan atau pernyataan pada masing-masing variabel penelitian tersebut dinyatakan reliabel. Hasil uji reliabilitas dapat dilihat pada Tabel 3 sebagai berikut:

Tabel 3.

Hasil Uji Reliabilitas

\begin{tabular}{clcc}
\hline No & \multicolumn{1}{c}{ Variabel } & Cronbach's Alpha & Keterangan \\
\hline 1 & Pengendalian Internal $\left(\mathrm{X}_{1}\right)$ & 0,992 & Reliabel \\
2 & Moralitas Individu $\left(\mathrm{X}_{2}\right)$ & 0,964 & Reliabel \\
3 & Budaya Etis Organisasi $\left(\mathrm{X}_{3}\right)$ & 0,962 & Reliabel \\
4 & Kecenderungan Kecurangan Akuntansi $(\mathrm{Y})$ & 0,984 & Reliabel \\
\hline
\end{tabular}
Sumber: Data diolah, 2018

Berdasarkan Tabel 3 menunjukkan bahwa keempat variabel penelitian yaitu pengendalian internal, moralitas individu, budaya etis organisasi, dan 
I Dewa Gede Praditya Chandrayatna dan Maria Madiatrix Ratna Sari. Pengaruh ...

kecenderungan kecurangan akuntansi memiliki nilai cronbach alpha lebih besar dari 0,60. Sehingga, dapat disimpulkan bahwa pernyataan dalam kuesioner penelitian ini reliabel dan layak dijadikan instrumen penelitian.

Statistik deskriptif digunakan untuk memberikan gambaran dari suatu data yang dilihat dari jumlah sampel, nilai minimum, nilai maksimum, nilai rata-rata (mean), dan standar deviasi dari masing-masing variabel. Informasi mengenai statistik deskriptif variabel penelitian ini dapat dilihat pada Tabel 4 sebagai berikut:

Tabel 4.

Hasil Analisis Statistik Deskriptif

\begin{tabular}{lccccc}
\hline \multicolumn{1}{c}{ Variabel } & N & Minimum & Maksimum & Mean & $\begin{array}{c}\text { Standar } \\
\text { Deviasi }\end{array}$ \\
\hline Pengendalian Internal $\left(\mathrm{X}_{1}\right)$ & 172 & 27 & 108 & 82,61 & 23,903 \\
Moralitas Individu $\left(\mathrm{X}_{2}\right)$ & 172 & 6 & 24 & 19,10 & 6,148 \\
Budaya Etis Organisasi $\left(\mathrm{X}_{3}\right)$ & 172 & 5 & 20 & 15,37 & 4,568 \\
Kecenderungan Kecurangan & 172 & 14 & 56 & 26,97 & 11,459 \\
Akuntansi (Y) & & & & & \\
Valid N (listwise) & 172 & & & & \\
\hline Sumber: Data diolah, 2018 & & & &
\end{tabular}

Sumber: Data diolah, 2018

Berdasarkan hasil pengujian statistik deskriptif pada Tabel 4 jumlah

pengamatan $(\mathrm{N})$ dalam penelitian ini berjumlah 172. Nilai terendah dari data ditunjukkan oleh skor minimum, sedangkan nilai tertinggi dari data ditunjukkan oleh skor maksimum. Nilai mean dari variabel menunjukkan besarnya rata-rata penerapan variabel tersebut dan standar deviasi menunjukkan penyimpangan nilai variabel terhadap nilai rata-ratanya.

Variabel pengendalian internal memiliki nilai minimum sebesar 27 dan nilai maksimum sebesar 108. Nilai rata-rata dari pengendalian internal adalah 82,61. Ini menunjukkan bahwa nilai rata-rata variabel pengendalian internal mendekati nilai maksimum daripada nilai minimumnya. Hal ini menandakan pengendalian internal di PT. BPD Bali baik. Nilai standar deviasi sebesar 23,903 yang tidak 
melebihi dua kali nilai rata-ratanya menunjukkan bahwa sebaran data baik. Nilai rata-rata sebesar 82,61 yang apabila dibagi dengan 27 item pernyataan akan menghasilkan nilai sebesar 3,06. Hal ini mencerminkan bahwa kecenderungan responden setuju atas pernyataan pengendalian internal dalam kuesioner.

Variabel moralitas individu memiliki nilai minimum sebesar 6 dan nilai maksimum sebesar 24. Nilai rata-rata dari moralitas individu adalah 19,10. Ini menunjukkan bahwa nilai rata-rata variabel moralitas individu mendekati nilai maksimum daripada nilai minimumnya. Hal ini menandakan moralitas individu pegawai PT. BPD Bali tinggi. Nilai standar deviasi sebesar 6,148 yang tidak melebihi dua kali nilai rata-ratanya menunjukkan bahwa sebaran data baik. Nilai rata-rata sebesar 19,10 yang apabila dibagi dengan 6 item pernyataan akan menghasilkan nilai sebesar 3,18. Hal ini mencerminkan bahwa kecenderungan responden setuju atas pernyataan moralitas individu dalam kuesioner.

Variabel budaya etis organisasi memiliki nilai minimum sebesar 5 dan nilai maksimum sebesar 20. Nilai rata-rata dari budaya etis organisasi adalah 15,37 . Ini menunjukkan bahwa nilai rata-rata variabel budaya etis organisasi mendekati nilai maksimum daripada nilai minimumnya. Hal ini menandakan budaya etis organisasi di PT. BPD Bali baik. Nilai standar deviasi sebesar 4,568 yang tidak melebihi dua kali nilai rata-ratanya menunjukkan bahwa sebaran data baik. Nilai rata-rata sebesar 15,37 yang apabila dibagi dengan 5 item pernyataan akan menghasilkan nilai sebesar 3,07. Hal ini mencerminkan bahwa kecenderungan responden setuju atas pernyataan budaya etis organisasi dalam kuesioner.

Variabel kecenderungan kecurangan akuntansi memiliki nilai minimum 
sebesar 14 dan nilai maksimum sebesar 56. Nilai rata-rata dari kecenderungan kecurangan akuntansi adalah 26,97. Ini menunjukkan bahwa nilai rata-rata variabel kecenderungan kecurangan akuntansi mendekati nilai minimum daripada nilai maksimumnya. Hal ini menandakan kecenderungan kecurangan akuntansi di PT. BPD Bali rendah. Nilai standar deviasi sebesar 11,459 yang tidak melebihi dua kali nilai rata-ratanya menunjukkan bahwa sebaran data baik. Nilai rata-rata sebesar 26,97 yang apabila dibagi dengan 14 item pernyataan akan menghasilkan nilai sebesar 1,93. Hal ini mencerminkan bahwa kecenderungan responden tidak setuju atas pernyataan kecenderungan kecurangan akuntansi dalam kuesioner.

Uji normalitas bertujuan untuk menguji apakah residual dari model regresi yang dibuat berdistribusi normal. Data populasi dikatakan berdistribusi normal bila koefisien Asymp. Sign. (2-tailed) lebih besar dari $\alpha=0,05$ (Ghozali, 2016: 157) Hasil dari uji normalitas dapat dilihat pada Tabel 5 sebagai berikut:

Tabel 5.

Hasil Uji Normalitas

\begin{tabular}{lc}
\hline & Unstandardized Residual \\
\hline $\mathrm{N}$ & 172 \\
Kolmogorov-Smirnov $\mathrm{Z}$ & 0,062 \\
Asymp. Sig. (2-tailed) & 0,099 \\
\hline Sumber: Data diolah, 2018 &
\end{tabular}

Pada Tabel 5 menunjukkan bahwa nilai Kolmogorov-Smirnov (K-S) sebesar 0,062 dan nilai Asymp. Sig. (2-tailed) sebesar 0,099. Hal tersebut menunjukkan bahwa model persamaan regresi berdistribusi normal, dikarenakan nilai Asymp. Sig. (2-tailed) sebesar 0,099 lebih besar dari alpha 0,05.

Uji multikolinearitas bertujuan untuk menguji apakah pada model regresi ditemukan adanya korelasi antar variabel bebas. Jika nilai tolerance lebih dari 10 persen dan VIF kurang dari 10, maka dikatakan tidak ada multikolinearitas 
(Suyana Utama, 2016: 111). Hasil dari uji multikolinearitas dapat dilihat pada Tabel 6 sebagai berikut:

Tabel 6.

Hasil Uji Multikolinearitas

\begin{tabular}{lccc}
\hline \multicolumn{1}{c}{ Variabel } & \multicolumn{2}{c}{ Collinearity Statistic } & Keterangan \\
& Tolerance & VIF & \\
\hline Pengendalian Internal $\left(\mathrm{X}_{1}\right)$ & 0,291 & 3,435 & Bebas Multikolinearitas \\
Moralitas Individu $\left(\mathrm{X}_{2}\right)$ & 0,281 & 3,562 & Bebas Multikolinearitas \\
Budaya Etis Organisasi $\left(\mathrm{X}_{3}\right)$ & 0,312 & 3,206 & Bebas Multikolinearitas \\
\hline
\end{tabular}

Sumber: Data diolah, 2018

Berdasarkan Tabel 6 dapat dilihat hasil uji multikolinearitas yang menunjukkan bahwa masing-masing variabel bebas memiliki nilai tolerance lebih besar dari 10 persen $(0,10)$ dan nilai VIF lebih kecil dari 10 . Hal ini menunjukkan bahwa tidak terjadi multikolinearitas antar variabel bebas dalam model regresi.

Uji heteroskedastisitas bertujuan untuk menguji apakah dalam model regresi terjadi ketidaksamaan varians dari residual satu pengamatan ke pengamatan lain. Jika tidak mengandung heteroskedastisitas, nilai signifikan variabel bebas terhadap nilai absolute residual lebih besar dari $\alpha=0,05$. Hasil dari uji heteroskedastisitas dapat dilihat pada Tabel 7 sebagai berikut:

Tabel 7.

Hasil Uji Heteroskedastisitas

\begin{tabular}{lcc}
\hline \multicolumn{1}{c}{ Variabel } & Sig. & Keterangan \\
\hline Pengendalian Internal $\left(\mathrm{X}_{1}\right)$ & 0,640 & Bebas Heteroskedastisitas \\
Moralitas Individu $\left(\mathrm{X}_{2}\right)$ & 0,457 & Bebas Heteroskedastisitas \\
Budaya Etis Organisasi $\left(\mathrm{X}_{3}\right)$ & 0,692 & Bebas Heteroskedastisitas \\
\hline
\end{tabular}

Sumber: Data diolah, 2018

Berdasarkan Tabel 7 dapat dilihat bahwa nilai signifikansi dari masingmasing variabel tersebut lebih besar dari 0,05. Sehingga, dapat disimpulkan bahwa seluruh variabel tersebut terbebas dari gejala heteroskedastisitas.

Uji regresi linear berganda merupakan model yang digunakan untuk menganalisis pengaruh lebih dari satu variabel independen terhadap satu variabel 
dependen. Uji ini digunakan untuk mengetahui pengaruh pengendalian internal $\left(\mathrm{X}_{1}\right)$, moralitas individu $\left(\mathrm{X}_{2}\right)$ dan budaya etis organisasi $\left(\mathrm{X}_{3}\right)$ pada kecenderungan kecurangan akuntansi (Y) di PT. Bank Pembangunan Daerah Bali. Analisis ini dilakukan dengan menggunakan bantuan program Statistical Package for Social Science (SPSS) versi 22. Hasil regresi linear berganda disajikan pada Tabel 8 sebagai berikut:

Tabel 8.

Hasil Uji Regresi Linear Berganda

\begin{tabular}{|c|c|c|c|c|c|c|}
\hline \multirow{2}{*}{ Model } & \multicolumn{2}{|c|}{$\begin{array}{c}\text { Unstandardized } \\
\text { Coefficients }\end{array}$} & \multirow{2}{*}{$\begin{array}{c}\text { Standardized } \\
\text { Coefficients } \\
\text { Beta }\end{array}$} & \multirow[b]{2}{*}{$\mathrm{t}$} & \multirow{2}{*}{ Sig. } & \multirow{2}{*}{$\begin{array}{l}\text { Hasil Uji } \\
\text { Hipotesis }\end{array}$} \\
\hline & $\mathrm{B}$ & $\begin{array}{l}\text { Std. } \\
\text { Error }\end{array}$ & & & & \\
\hline (Constant) & 65,829 & 1,763 & & 37,335 & 0,000 & \\
\hline $\mathrm{X} 1$ & $-0,115$ & 0,037 & $-0,223$ & $-3,142$ & 0,002 & Diterima \\
\hline $\mathrm{X} 2$ & $-0,883$ & 0,159 & $-0,401$ & $-5,549$ & 0,000 & Diterima \\
\hline X3 & $-0,828$ & 0,184 & $-0,309$ & $-4,505$ & 0,000 & Diterima \\
\hline Adjusted $R^{2}$ & & & & & 0,750 & \\
\hline $\mathrm{F}_{\text {hitung }}$ & & & & & 171,653 & \\
\hline Sig. F & & & & & 0,000 & \\
\hline
\end{tabular}

Sumber: Data diolah, 2018

Berdasarkan Tabel 8 diperoleh persamaan regresi linear berganda sebagai berikut:

$$
\mathrm{Y}=65,829-0,115 \mathrm{X}_{1}-0,883 \mathrm{X}_{2}-0,828 \mathrm{X}_{3}+\varepsilon
$$

Nilai konstanta regresi sebesar 65,829 menunjukkan bahwa apabila nilai pengendalian internal, moralitas individu dan budaya etis organisasi sama dengan nol, maka nilai kecenderungan kecurangan akuntansi sebesar 65,829 satuan persepsi. Nilai koefisien regresi variabel pengendalian internal sebesar $-0,115$. Hal ini berarti bahwa jika pengendalian internal meningkat sebesar satu satuan persepsi, maka kecenderungan kecurangan akuntansi akan mengalami penurunan sebesar 0,115 satuan persepsi dengan asumsi variabel bebas lainnya konstan. Nilai koefisien regresi variabel moralitas individu sebesar $-0,883$. Hal ini berarti bahwa 
jika moralitas individu meningkat sebesar satu satuan persepsi, maka kecenderungan kecurangan akuntansi akan mengalami penurunan sebesar 0,883 satuan persepsi dengan asumsi variabel bebas lainnya konstan. Nilai koefisien regresi variabel budaya etis organisasi sebesar $-0,828$. Hal ini berarti bahwa jika budaya etis organisasi meningkat sebesar satu satuan persepsi, maka kecenderungan kecurangan akuntansi akan mengalami penurunan sebesar 0,828 satuan persepsi dengan asumsi variabel bebas lainnya konstan.

Uji koefisien determinasi merupakan goodness of fit dari persamaan regresi yang dibuat dalam penelitian, yaitu variasi dari variabel dependen yang mampu dijelaskan oleh variabel independen (Suyana Utama, 2016: 78). Nilai Adjusted $R^{2}$ adalah sebesar 0,750 . Hal ini berarti bahwa 75 persen variasi kecenderungan kecurangan akuntansi dipengaruhi oleh variasi pengendalian internal, moralitas individu dan budaya etis organisasi. Sedangkan, sisanya sebesar 25 persen dipengaruhi oleh faktor lain di luar model penelitian.

Uji kelayakan model dilakukan dengan uji $\mathrm{F}$ yang bertujuan untuk menguji apakah semua variabel bebas yang dimasukkan dalam model mempunyai pengaruh secara bersama-sama terhadap variabel dependen. Nilai dari uji $\mathrm{F}$ sebesar 171,653 dan nilai sig. $F$ yakni 0,000 lebih kecil dari nilai $\alpha=0,05$. Hal ini menunjukkan bahwa model persamaan dalam penelitian ini layak untuk digunakan.

Uji t digunakan untuk menguji signifikansi atau pentingnya variabel independen terhadap variabel dependen secara individual atau parsial. Level of significant $(\alpha)$ yang digunakan adalah 0,05 . Nilai signifikansi uji t untuk variabel 
pengendalian internal sebesar 0,002 dengan nilai koefisien beta sebesar -0,115. Nilai signifikansi uji t sebesar 0,002 lebih kecil dari 0,05 mengindikasikan bahwa hipotesis pertama $\left(\mathrm{H}_{1}\right)$ diterima. Hal ini berarti bahwa pengendalian internal berpengaruh negatif pada kecenderungan kecurangan akuntansi. Semakin baik pengendalian internal di PT. BPD Bali, maka dapat mengurangi kecenderungan kecurangan akuntansi. Jika ada pengawasan dan evaluasi atas aktivitas-aktivitas operasional secara terus-menerus dalam organisasi, akan membantu dalam mengurangi adanya kecenderungan kecurangan akuntansi.

Hasil penelitian ini mendukung teori fraud triangle yang menjelaskan tiga faktor penyebab seseorang melakukan tindakan kecenderungan kecurangan akuntansi, salah satunya adalah kesempatan (opportunity). Peluang merupakan suatu situasi yang mengakibatkan individu melakukan kecurangan secara diamdiam. Faktor kesempatan dapat mengakibatkan pelaku dengan leluasa melakukan tindakan kecurangan. Dengan adanya pengendalian internal yang efektif, maka akan mengurangi faktor kesempatan yang dapat mendorong dilakukannya tindakan kecurangan akuntansi. Pengendalian internal juga berperan dalam mengidentifikasi dan menganalisis risiko-risiko yang relevan dalam penyusunan laporan keuangan, sehingga dapat meminimalkan kecenderungan kecurangan akuntansi.

Hasil penelitian ini mendukung penelitian sebelumnya yang dilakukan dilakukan oleh Putri (2014), Sari dkk. (2015), Lestari dan Supadmi (2017) menyatakan bahwa pengendalian internal berpengaruh negatif dan signifikan pada kecurangan akuntansi. Hasil tersebut juga sejalan dengan penelitian yang 
dilakukan oleh Restiana dan Amirya (2015) menunjukkan bahwa efektivitas sistem pengendalian internal berpengaruh negatif terhadap terjadinya fraud.

Nilai signifikansi uji t untuk variabel moralitas individu sebesar 0,000 dengan nilai koefisien beta sebesar $-0,883$. Nilai signifikansi uji t sebesar 0,000 lebih kecil dari 0,05 mengindikasikan bahwa hipotesis kedua $\left(\mathrm{H}_{2}\right)$ diterima. Hal ini berarti bahwa moralitas individu berpengaruh negatif pada kecenderungan kecurangan akuntansi. Semakin tinggi moralitas individu pegawai PT. BPD Bali, maka dapat mengurangi kecenderungan kecurangan akuntansi. Moralitas dapat terjadi jika seseorang berperilaku baik dalam menjalankan tanggung jawabnya dan bukan dikarenakan mencari keuntungan.

Hasil penelitian ini mendukung teori perkembangan moral Kohlberg yang menjelaskan bahwa penalaran moral sebagai landasan dari perilaku etis. Tingkat penalaran moral individu akan memengaruhi perilaku etis mereka (Liyanarachchi dan Newdick, 2009). Kohlberg mengemukakan bahwa moral berkembang melalui tiga tingkatan yaitu penalaran prakonvensional, penalaran konvensional dan pasca-konvensional. Semakin tinggi moralitas individu, maka individu akan lebih memperhatikan kepentingan secara universal daripada dirinya sendiri. Sehingga, setiap individu akan berusaha melakukan hal yang benar dalam menjalankan tanggung jawabnya dan menghindari kecenderungan kecurangan akuntansi.

Hasil penelitian ini mendukung penelitian sebelumnya yang dilakukan oleh Indriastuti dkk. (2016) dan Udayani dan Sari (2017) yang menyatakan bahwa moralitas individu berpengaruh negatif terhadap kecurangan akuntansi. Hasil tersebut juga sejalan dengan penelitian yang dilakukan oleh Anastasia dan Sparta 
I Dewa Gede Praditya Chandrayatna dan Maria Madiatrix Ratna Sari. Pengaruh ...

(2014) serta Eliza (2015) yang berpendapat bahwa moralitas individu berpengaruh negatif dan signifikan terhadap tingkat kecenderungan kecurangan akuntansi

Nilai signifikansi uji t untuk variabel budaya etis organisasi sebesar 0,000 dengan nilai koefisien beta sebesar -0,828. Nilai signifikansi uji t sebesar 0,000 lebih kecil dari 0,05 mengindikasikan bahwa hipotesis ketiga $\left(\mathrm{H}_{3}\right)$ diterima. Hal ini berarti bahwa budaya etis organisasi berpengaruh negatif pada kecenderungan kecurangan akuntansi. Semakin baik budaya etis organisasi di PT. BPD Bali, maka dapat mengurangi kecenderungan kecurangan akuntansi. Jika suatu organisasi telah menanamkan budaya etis yang baik, seperti kecurangan akuntansi merupakan tindakan yang buruk dan merugikan banyak pihak maka pegawai cenderung tidak akan melakukan kecurangan akuntansi.

Hasil penelitian ini mendukung teori fraud triangle yang menjelaskan tiga faktor penyebab seseorang melakukan tindakan kecenderungan kecurangan akuntansi, salah satunya adalah rasionalisasi (rasionalization). Faktor rasionalisasi menjelaskan bahwa sikap, karakter, atau serangkaian nilai-nilai etis yang memperbolehkan pegawai untuk melakukan tindakan yang tidak jujur, atau mereka berada dalam lingkungan yang cukup menekan sehingga mendorong mereka merasionalisasi tindakan yang tidak jujur. Dengan diterapkannya budaya etis organisasi yang baik akan mengurangi terjadinya faktor rasionalisasi, seperti merasionalisasi tindakan kecurangan akuntansi.

Hasil penelitian ini mendukung penelitian sebelumnya yang dilakukan oleh Artini dkk. (2014), Lestari dkk. (2015) dan Zainuddin (2016) yang 
menyatakan bahwa budaya etis organisasi berpengaruh negatif dan signifikan terhadap kecenderungan kecurangan akuntansi.

Implikasi teoritis dalam penelitian ini adalah mendukung teori fraud triangle yang menjelaskan tiga faktor penyebab seseorang melakukan tindakan kecenderungan kecurangan akuntansi yaitu tekanan, kesempatan dan rasionalisasi. Hasil penelitian ini juga mendukung teori perkembangan moral Kohlberg yang menjelaskan bahwa penalaran moral sebagai landasan dari perilaku etis. Selain itu, penelitian ini mampu menambah informasi, wawasan dan mengembangkan ilmu pengetahuan mengenai pengaruh pengendalian internal, moralitas individu dan budaya etis organisasi pada kecenderungan kecurangan akuntansi.

Implikasi praktis dalam penelitian ini ialah dapat memberikan masukan bagi PT. Bank Pembangunan Daerah Bali dalam pengambilan keputusan terkait dengan pengendalian internal, moralitas individu dan budaya etis organisasi sehingga dapat menurunkan tingkat kecenderungan kecurangan akuntansi. Selain itu, penelitian ini memberikan pertimbangan bagi pihak manajemen PT. BPD Bali dalam menerapkan peraturan, kebijakan dan bahan evaluasi terhadap kinerja pegawai guna mencegah terjadinya kecurangan akuntansi. Bagi peneliti selanjutnya, penelitian ini dapat dijadikan acuan bagi penelitian yang sejenis dan sebagai bahan rujukan dalam menambah informasi yang diperlukan.

\section{SIMPULAN}

Pengendalian internal berpengaruh negatif pada kecenderungan kecurangan akuntansi di PT. Bank Pembangunan Daerah Bali. Hal ini berarti bahwa semakin 
baik pengendalian internal, maka tingkat terjadinya kecenderungan kecurangan akuntansi di PT. BPD Bali akan semakin menurun. Dengan adanya pengawasan dan evaluasi atas aktivitas-aktivitas operasional secara terus-menerus, akan membantu dalam mengurangi adanya kecenderungan kecurangan akuntansi. Moralitas individu berpengaruh negatif pada kecenderungan kecurangan akuntansi di PT. Bank Pembangunan Daerah Bali. Hal ini berarti bahwa semakin tinggi moralitas individu pegawai PT. BPD Bali, maka tingkat kecenderungan kecurangan akuntansi semakin rendah. Semakin tinggi moralitas individu, maka individu akan lebih memperhatikan kepentingan secara universal daripada dirinya sendiri. Sehingga, setiap individu akan berusaha melakukan hal yang benar dan menghindari terjadinya kecenderungan kecurangan akuntansi. Budaya etis organisasi berpengaruh negatif pada kecenderungan kecurangan akuntansi. Hal ini berarti bahwa semakin baik budaya etis organisasi di PT. BPD Bali, maka semakin rendah terjadinya kecenderungan kecurangan akuntansi. Jika suatu organisasi telah menanamkan budaya etis yang baik, seperti kecurangan akuntansi merupakan tindakan yang buruk dan merugikan banyak pihak, maka pegawai cenderung tidak akan melakukan kecurangan akuntansi.

Berdasarkan hasil analisis statistik deskriptif menunjukkan bahwa pengendalian internal di PT. BPD Bali sudah kuat, namun dapat disarankan agar PT. BPD Bali meningkatkan keefektifan dari pengawasan yang dilakukan. Hal tersebut bertujuan untuk mendorong pegawai dalam melaksanakan tugasnya dengan baik dan sesuai peraturan yang berlaku, mendorong setiap pegawai untuk melaporkan pegawai lain yang melakukan kecurangan, serta memberikan sanksi 
yang tegas untuk pegawai yang melakukan kecurangan. Dari segi moralitas, pegawai PT. BPD Bali memiliki tingkatan moralitas individu yang tinggi. Namun, dapat disarankan agar PT. BPD Bali meningkatkan dilakukannya pendidikan dan pelatihan pengembangan moral bagi setiap pegawainya. Hal tersebut bertujuan untuk melatih setiap pegawai dalam mengambil tindakan yang benar dan menghindari dilakukannya tindakan tidak etis apabila dihadapi dengan dilema etika. Bagi peneliti selanjutnya disarankan untuk melakukan penelitian secara mendalam mengenai kecenderungan kecurangan akuntansi, sehingga dapat menghasilkan research finding yang sesuai antara teori dengan keadaan di lapangan baik pada sektor publik maupun swasta. Hal tersebut dikarenakan temuan penelitian ini menunjukkan PT. BPD Bali memiliki pengendalian internal yang baik, moralitas individu pegawai yang tinggi dan budaya etis organisasi yang baik, namun di PT. BPD Bali masih terjadi kasus mengenai kecenderungan kecurangan akuntansi.

\section{REFERENSI}

Anastasia, \& Sparta (2014). Pengaruh Keefektifan Pengendalian Internal, Persepsi Kesesuaian Kompensasi, dan Moralitas Individu terhadap Kecenderungan Akuntansi (Studi pada Perusahaan Swasta di Wilayah Tangerang dan Jakarta). Jurnal ULTIMA Accounting, 6(1), 1-26.

Apriadi, R. N., \& Fachriyah, N. (2014). Determinan Terjadinya Fraud di Institusi Pemerintahan. Jurnal Ilmiah Mahasiswa FEB Universitas Brawijaya, 3(1), $1-25$.

Ariyanti, F. (2016). Dalam 2 Tahun, Ada 108 Kasus Kejahatan Perbankan.https://www.liputan6.com/bisnis/read/2651413/dalam-2-tahunada-108-kasus-kejahatan-perbankan. Diakses 19 April 2018. 
Artini, N. L. E. A., Adiputra, I. M. P., \& Herawati, N. T. (2014). Pengaruh Budaya Etis Organisasi dan Efektivitas Pengendalian Internal terhadap Kecenderungan Kecurangan Akuntansi pada Satuan Kerja Perangkat Daerah (SKPD) Kabupaten Jembrana. E-Journal Universitas Pendidikan Ganesha, 2(1), 1-12.

Association of Certified Faud Examiners. (2014). Report To the Nations on Occupational Fraud and Abuse. Global Fraud Study, 15(2), 20. https://doi.org/http://dx.doi.org/10.2139/ssrn.2222608

Bhasin, M. L. (2013). Corporate Accounting Fraud: A Case Study of Satyam Computers Limited. Open Journal of Accounting, 2(2), 26-38. https://doi.org/10.4236/ojacct.2013.22006

Chairunnisa, N. (2018). Kasus Korupsi Tahun 2017, ICW: Kerugian Negara Rp 6,5 Triliun.https://nasional.tempo.co/read/1062534/kasus-korupsi-tahun2017-icw-kerugian-negara-rp-65-triliun. Diakses 18 April 2018.

Coram, P., Ferguson, C., \& Moroney, R. (2008). Internal Audit, Alternative Internal Audit Structures and the Level of Misappropriation of Assets Fraud. Journal Accounting \& Finance, 48(4), 543-559.

Eliza, Y. (2015). Pengaruh Moralitas Individu dan Pengendalian Internal terhadap Kecenderungan Kecurangan Akuntansi (Studi Empiris pada SKPD di Kota Padang). Jurnal Akuntansi, 4(1), 86-100. https://doi.org/10.1017/CBO9781107415324.004

Fachrunisa, A., Hasan, A., \& Safitri, D. (2015). Pengaruh Keefektifan Pengendalian Internal, Keadilan Distributif, Keadilan Prosedural, dan Budaya Etis Organisasi terhadap Kecenderungan Kecurangan (Fraud) Akuntansi (Studi Empiris pada SKPD Kabupaten Kampar). Jurnal Online Mahasiswa Fakultas Ekonomi Universitas Riau, 2(2), 1-15.

Gaviria, A. (2002). Assessing the Effects of Corruption and Crime on Firm Performance: Evidence from Latin American. Emerging Markets Review, 3(3), 245-268. https://doi.org/10.1016/S1566-0141(02)00024-9

Ghozali, I. (2016). Aplikasi Analisis Multivariete dengan Program IBM SPSS 21. Semarang: Badan Penerbit Universitas Diponegoro.

Hogan, C. E., Rezaee, Z., Riley, R. A., \& Velury, U. K. (2008). Financial Statement Fraud: Insights from the Academic Literature. Auditing: A Journal of Practice \& Theory, 27(2), 231-252. https://doi.org/10.2308/aud.2008.27.2.231 
Humas Komisi Pemberantasan Korupsi. (2018). Indeks Persepsi Korupsi 2017, Skor Indonesia di Angka 37.https://www.kpk.go.id/id/berita/berita-kpkkegiatan/4164-indeks-persepsi-korupsi-2017-skor-indonesia-di-angka-37. Diakses 20 April 2018.

Indriastuti, D. E., Agusdin, \& Animah. (2016). Analisis Pengaruh Asimetri Informasi, Pengendalian Internal, Persepsi Kesesuaian Kompensasi, Moralitas Individu, dan Ketaatan Aturan Akuntansi terhadap Kecurangan Akuntansi. Jurnal InFestasi, 12(2), 115-130.

Kuria, P., \& Muturi, W. (2015). The Relationship between Auditors Experience and Fraud Detection. European Journal of Business and Social Sciences, 4(4), 79-86.

Leng, J., \& Zhang, L. (2014). Research and Discussing on Internal Control Auditing. Modern Economy, 585-790. https://doi.org/10.4236/me.2014.57072

Lestari, K. A., Purnamawati, I. G. A., \& Herawati, N. T. (2015). Pengaruh Pengendalian Internal dan Budaya Etis Organisasi terhadap Kecenderungan Kecurangan (Fraud) pada Koperasi Simpan Pinjam di Kecamatan Buleleng. E-Journal Universitas Pendidikan Ganesha, 3(1), 1-11.

Lestari, N. K. L., \& Supadmi, N. L. (2017). Pengaruh Pengendalian Internal, Integritas, dan Asimetri Informasi pada Kecurangan Akuntansi. E-Jurnal Akuntansi Universitas Udayana, 21(1), 389-417.

Liu, X. (2016). A Literature Review on the Definition of Corruption and Factors Affecting the Risk of Corruption. Open Journal of Social Sciences, 4(7), 171-177. https://doi.org/10.4236/ce.2016.77112

Liyanarachchi, G., \& Newdick, C. (2009). The Impact of Moral Reasoning and Retalitation on Whistle-Blowing: New Zealand Evidence. Journal of Business Ethics, 8(9), 37-57. https://doi.org/10.1007/s10551-008-9983-x

Mangala, D., \& Kumari, P. (2017). Auditors' Perceptions of the Effectiveness of Fraud Prevention and Detection Methods. Indian Journal of Corporate Governance, 10(2), 118-142. https://doi.org/10.1177/0974686217738683

Muhammad, R., \& Ridwan. (2017). Pengaruh Kesesuaian Kompensasi, Penerapan Sistem Informasi Akuntansi, dan Efektivitas Pengendalian Internal terhadap Kecurangan Akuntansi Studi pada Bank Perkreditan Rakyat (BPR) di Kota Banda Aceh. Jurnal Ilmiah Mahasiswa Ekonomi Akuntansi, 2(4), 136-145. https://doi.org/E-ISSN 2581-1002 
Mukino, Purnomo, E., \& Suntoro, I. (2016). Penerapan Model Moral Reasoning untuk Membentuk Moralitas dan Karakter Siswa pada PKn. Jurnal Studi Sosial, 4(1), 42-52.

Ozcan, A. (2016). Firm Characteristics and Accounting Fraud: A Multivariate Approach. Journal of Accounting, Finance and Auditing Studies, 2(2), 128144.

Putri, A. A. P. A. (2014). Pengaruh Keefektifan Pengendalian Internal dan Kepuasan Kerja terhadap Kecenderungan Kecurangan Akuntansi pada Dinas Pendapatan Pengelolaan Keuangan Aset Daerah Istimewa Yogyakarta. Jurnal Nominal, 3(1), 61-74.

Restiana, T., \& Amirya, M. (2015). Pengaruh Kesesuaian Kompensasi, Gaya Kepemimpinan, dan Efektivitas Sistem Pengendalian Internal Terhadap Fraud (Studi pada BPK RI Perwakilan Provinsi Kepulauan Bangka Belitung). Jurnal Ilmiah Mahasiswa FEB Universitas Brawijaya, 4(2), 1-17.

Salem, M. S. M. (2012). An Overview of Research on Auditor's Responsibility to Detect Fraud on Financial Statements. The Journal of Global Business Management, $\quad 8(2), \quad 218-229 . \quad$ Retrieved from http://search.proquest.com.ezaccess.library.uitm.edu.my/docview/131273733 7 ? accountid $=42518$

Sandi, E. P. (2016). Pelaku Fraud di Bank BPD Bali Habiskan 1,7 Miliar untuk Beli Rumah dan Mobil.http://bali.tribunnews.com/2016/02/24/pelaku-frauddi-bank-bpd-bali-habiskan-17-miliar-untuk-beli-rumah-dan-mobil. Diakses 20 April 2018.

Sari, N. L. P. P., Yuniarta, G. A., \& Adiputra, I. M. P. (2015). Pengaruh Efektifitas Sistem Pengendalian Internal, Ketaatan Aturan Akuntansi, Persepsi Kesesuaian Kompensasi dan Implementasi Good Governance terhadap Kecenderungan Fraud (Studi Empiris pada SKPD di Kabupaten Tabanan). E-Journal Universitas Pendidikan Ganesha, 3(1), 1-11.

Simanjuntak, S. N., Hasan, A., \& A, A. A. (2015). Pengaruh Independensi, Kompetensi, Skeptisme Profesional dan Profesionalisme terhadap Kemampuan Mendeteksi Kecurangan (Fraud) pada Auditor di BPK RI Perwakilan Provinsi Sumatera Utara. Jurnal Online Mahasiswa Fakultas Ekonomi Universitas Riau, 2(2), 1-13.

Sugiyono. (2017). Metode Penelitian Bisnis (Pendekatan Kuantitatif, Kualitatif, Kombinasi, dan $R \& D)$ ). Bandung: CV Alfabeta.

Suyana Utama, M. (2016). Aplikasi Analisis Kuantitatif untuk Ekonomi dan Bisnis. Denpasar: Sastra Utama. 
Tuanakotta, T. M. (2010). Akuntansi Forensik \& Audit Investigatif. In Edisi 2. Jakarta: Salemba Empat.

Udayani, A. A. K. F., \& Sari, M. M. R. (2017). Pengaruh Pengendalian Internal dan Moralitas Individu pada Kecenderungan Kecurangan Akuntansi. EJurnal Akuntansi Universitas Udayana, 18(3), 1774-1799. https://doi.org/10.24036/20171115

Wulandari, S., \& Zaky, A. (2014). Determinan Terjadinya Fraud di Instansi Pemerintahan (Persepsi pada Pegawai BPK RI Perwakilan Provinsi NTB). Jurnal Ilmiah Mahasiswa FEB Universitas Brawijaya, 3(2), 1-32.

Zainuddin. (2016). Efektifitas Pengendalian Internal, Budaya Etis Organisasi dan Ketaatan Aturan Akuntansi terhadap Kecenderungan Kecurangan Akuntansi. El Muhasaba Jurnal Akuntansi, 7(1), 37-50. 